\title{
Education and technology: new learning environments from a transformative perspective
}

\author{
Mercè Gisbert Cervera ${ }^{1}$ and Larry Johnson ${ }^{2}$ \\ 1. Rovira i Virgili University (URV), Spain | merce.gisbert@urv.cat \\ Submitted in: April 2015 \\ Accepted in: April 2015 \\ Published in: April 2015
}

\section{Recommended citation}

Gisbert Cervera, M., \& Johnson, L. (2015). Education and technology: new learning environments from a transformative perspective. RUSC. Universities and Knowledge Society Journal, 12(2). pp. 1-13. doi http://dx.doi.org/10.7238/rusc.v12i2.2570

\begin{abstract}
The process of digitization that is increasingly entering all aspects of our lives (personal, academic, professional and social) requires education to undergo a profound transformation, and communication and learning processes to be reformulated. Networks and the ability to access information and knowledge anytime and anywhere are enabling all spaces to become potential learning environments. To acquire the evidence we need, we must therefore investigate the real changes that are taking place as a result of digitization. This kind of research should enable us to transform educational activity in a broad sense.

In this context and with these objectives in mind, the first International Forum on Education and Technology (FIET) was designed and developed. At the Forum, experts and researchers from 16 countries from around the world worked together for a period of nine months to define the future lines of action for the Education and Technology binomial. These lines of action were divided into the following four categories: institutions and learning environments, citizens, teachers, and public policy. The final category, which encompasses all the previous three, is one that needs to be investigated and innovated in order to produce changes and improvements in the education system.
\end{abstract}

\section{Keywords}

key competences, culture, innovation, smart cities, social networks 


\section{Educación y tecnología: nuevos escenarios de aprendizaje desde una visión transformadora}

\section{Resumen}

La creciente digitalización de todos los ámbitos de la vida (personal, académico, profesional y social) exige una profunda transformación de la educación a la vez que propicia una reformulación de los procesos de comunicación y de aprendizaje. Las redes y el acceso a la información y al conocimiento en cualquier momento y lugar convierten cualquier espacio en un potencial escenario para aprender. Todo ello conduce a la necesidad de investigar para poder obtener evidencias de cuáles son los cambios reales que se producen a causa de la digitalización. Estas investigaciones deben permitir transformar la acción educativa en un sentido amplio.

En este contexto y con estos objetivos, se diseñó y desarrolló el primer Foro Internacional de Educación y Tecnología (FIET). Durante nueve meses, expertos e investigadores de 16 países distintos trabajaron conjuntamente para definir las líneas de acción futuras en el binomio educación y tecnología. Propusieron agruparlas en los siguientes ámbitos: instituciones y entornos de aprendizaje, ciudadanía, profesorado y políticas para avanzar en investigación e innovación, que enmarca el resto de líneas de acción, a fin de favorecer el cambio y la mejora de la educación.

\section{Palabras clave}

competencias clave, cultura, innovación, ciudades inteligentes y redes sociales 


\section{Introduction}

In the last two decades, technology has helped to construct new environments and new educational and cultural modalities (Castells, 2004) while also generating global networks for creating and defining new perspectives and approaches for education and culture, which should be the driving forces behind the development of any country.

In our geographical area, it is currently essential that proposals should be designed in accordance with the broad outlines of the Digital Agenda for Europe 2020 (EU, 2010) and the Digital Agenda for Catalonia 2020 (autonomous government of Catalonia, 2013), as well as with current prospective reports and analyses. All these reports and analyses highlight the importance of defining a future-oriented education strategy with a solid foundation that takes into account strategies from three perspectives: policies, leadership, and praxis (Horizon reports 2012, 2013, and 2014); economic-impact analysis (OECD, 2012), and the current challenge facing education to take advantage of the possibilities provided by the digital age to create new educational environments and strategies for the future. In both its reports and its actions, UNESCO emphasizes the need to recognize the potential of Information and Communication Technologies (ICTs) to be key elements for renewing education, promoting universal access to information and knowledge, fostering freedom of expression and the sustainable development of society, and making society more cultured, inclusive and equitable (Mansell \& Tremblay, 2013). As well as for modernizing educational institutions, technology has great potential for transforming training processes (Slavich and Zimbarno, 2012) and providing students with new learning opportunities and strategies (Katic, 2008). In this context, Ferrari (2012) suggested that the three main arguments for integrating ICTs in education are that they: have benefits for both teaching and learning, satisfy the need for digital competence to meet the challenges of today's society, and help to narrow the digital divide in order to ensure the active participation of citizens in the current context. Without technology, education will lack both the strategies and the solid foundation it needs to define policies and develop strategies that will ensure that both education and society are heading in the right direction.

With this framework and conception, the first FIET was designed from an international, global and multidisciplinary perspective that took into account not only formal but also non-formal and informal modes of education.

This first Forum was one of the initiatives held to commemorate the events of the Tercentenary of Catalonia (1714-2014). Within the Thought strategic line, the objectives of the Forum were to support and promote a series of environments for reflection, discussion, study and analysis in order to define what challenges Catalonia will face in the immediate and short term. Specifically, the Forum focused on analyzing the relationship between Technology and Education through collaborative work conducted by experts from Catalonia and the rest of the world, who shared their conclusions and made recommendations for the future.

Strategies as well as reflection and discussion forums should be developed to enable the formulation of questions on the incorporation and use of ICTs in education and to find scientifically validated answers to questions such as: Do we need new training environments? Do we need teachers with different profiles to the current one? Who should generate contents? How should information and knowledge be transmitted? What is the meaning and value of evaluation in technological environments? What is the significance of digital learning and how will it evolve? We need new, more flexible and more adaptable educational environments that integrate technology naturally, provide plenty of evidence about the education process, and foster innovation and creativity on the part of teachers and students alike (Horizon, 2014). 
The answers and evidence collected in response to the above questions, as well as to many others we could also formulate, should help us to consolidate educational development based on collaborative work that makes best use of human capital as a key element in integrating the various agents that participate in the educative process.

\section{International Forum on Education and Technology, a collaborative space for knowledge creation (FIET)}

Between September 2013 and June 2014 the FIET experts analyzed the status quo with regard to Education, Culture and Technology from a local perspective (Catalonia) but with an international projection (the rest of the world). The insight and vision of researchers from numerous fields of knowledge enabled a global and interdisciplinary analysis to be made. In total, the Forum was attended by 98 experts from 65 institutions from 16 different countries.

The Forum had two broad objectives:

1. To analyze, with scientific evidence and from an international perspective, the main research results from the 11 lines of work that were defined as strategic (see below).

2. To showcase the knowledge and experience existing in Catalonia in the fields of Education, Culture and Technology, and compare these with the international perspective in order to generate environments for future collaboration on research projects in education and educational technology.

These objectives were achieved through analysis, debate and the construction of education proposals for new learning environments from a technological and transformative perspective. The basic processes introduced during this first FIET were:

- Showcase the research being conducted and the knowledge being generated in Catalonia in the fields of education, culture and technology.

- Identify and select the best experiences in the areas of innovation and research being conducted in these fields.

- Identify the best specialists in these fields and invite them to take part in the first edition of FIET.

- Define and activate strategic projects for developing Education and Technology in the context of Catalonia but with an international perspective.

Next we present a summary of the contents of the four thematic axes and eleven thematic lines.

\subsection{Thematic axes [See Figure 1]}

The activities designed to meet the above objectives revolved around the four thematic axes and eleven thematic lines outlined below:

- Axis 1: This axis comprised the main areas involved in the education process in a generic sense from the perspective of the digital society in order to define how they can be reformulated. 
- Axis 2: This axis comprised elements that facilitate the construction of knowledge ranging from the education context to knowledge transfer processes in digital environments.

- Axis 3: This axis comprised all aspects that enable analysis of the responsible use of technology for cooperation and collaboration purposes so that the digital inclusion of citizens can be assumed and their needs respected.

- Axis 4: This axis comprised all content associated with the specific means of dissemination and outreach of media adapted to today's society.

Below we present a graphical representation of the eleven thematic lines, each located within its thematic axis:

Figure 1. Configuration of the thematic axes and thematic lines of the first FIET

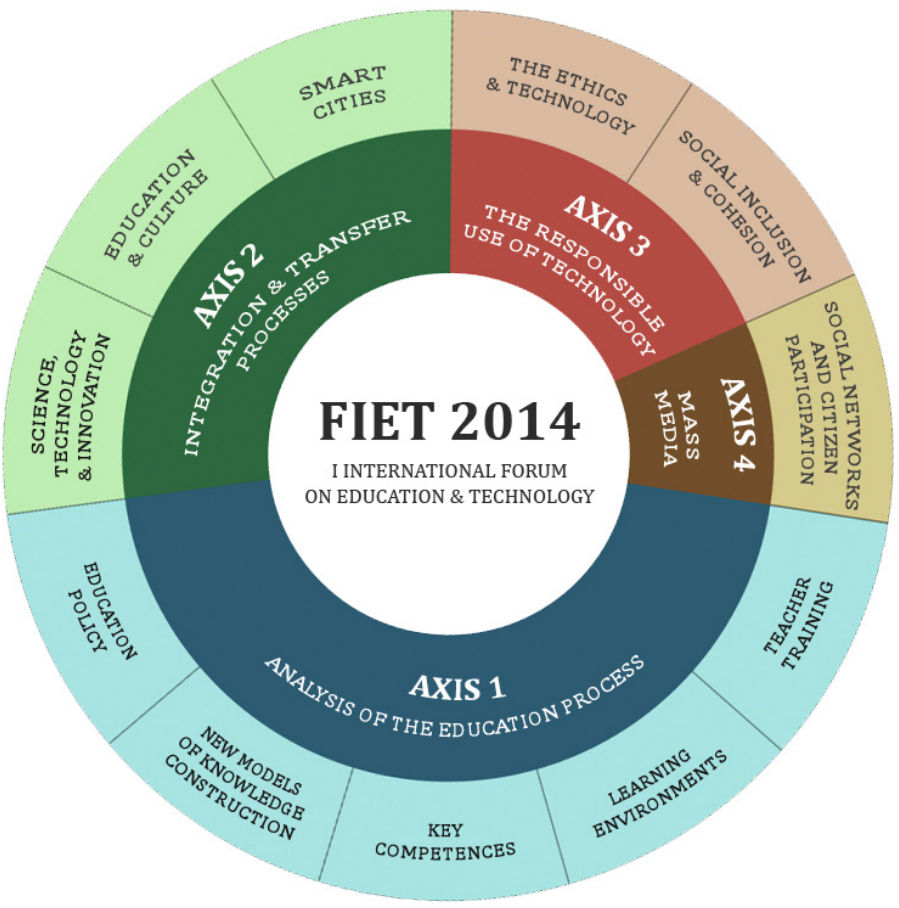

Below is a summary of the key topics and main contents of these eleven thematic lines, which were intended to cover the whole spectrum of education in the digital context.

1) Education policy: The impact of education policies on the education-technology binomial aimed at analyzing: equity in the social system (Martínez and Albaigés, 2013), lifelong learning, the structure and content of the basic curriculum (Sarramona, 2011), the digital models of education administration, the autonomy of teaching centers and school management, support services for teaching centers (Gairín, 2005, Godó, 2010), teacher training and professional development, guidance and lifelong accompaniment, social involvement in education, evaluation and supervision, and research (Bonal and Verger, 2013) and innovation as organizational elements of the training process, also in a digital context (Gairín, Armengol and Muñoz, 2010). 
2) New models of knowledge construction: The development of understanding of the dynamics of knowledge construction (Kerehik, Mishra, Fahnoe and Terry, 2012) and analysis of the consequences of these changes on the role of teachers and the purposes of education (Linn and Eylon, 2011) in the communicative context of the twenty-first century and in lifelong learning scenarios that are increasingly shaped and mediated by ICTs (Mahiri, 2011).

3) Key competences: The Information Society and the knowledge economy (Martínez Bonafé, 2012) have made it necessary for people to acquire new cognitive and technical competences and abilities (Brown, Lander, Ashton, 2011) in order to meet the challenges of an increasingly complex and changing digital context (Mishra, Kerenlik, 2011). This is one of the great challenges faced by training and that must be met from the perspective of lifelong learning, since training must be structured along a continuum (EU, 2007).

4) Learning environments: Digital environments are created non-exclusively, in different forms, and with a variety of uses (Salinas, 2005, Gros, 2012). These range from the management of training activities (EVEAs) to the personalized, distributed use of the communicative and informational options provided by the Internet - especially social networks (PLEs and MOOCs) - (Adell, 2013, Adell and Castañeda, 2013, Kartensi, 2013) via environments whose innovative component is based on the pedagogical exploitation of advanced technologies such as virtual reality and augmented reality (MUVLEs) (Dalgarno and Lee, 2010). Such environments enable the generation of complex, contextualized and user-centered realities.

5) Teacher training: Schools cannot afford to remain detached from the fast-moving changes that are taking place and have therefore made innovation one of their main priorities (Pedró, 2011). While knowledge and mastery of digital tools and processes are guarantees of equity in the education system, schools also have to face the challenge of making digital tools and applications available to all their pupils without neglecting any aspect of their educational function (Barber and Mourshed, 2007). In this context, teachers must also acquire the digital competences they need to be able to assume their leading role in education processes in both formal and non-formal environments (Twining, Rallaghelli, Albion and Knezek, 2013).

6) Science, Technology and Innovation: Education models must be brought up to date (Granier and Renda, 2012) to include concepts such as: societal involvement, the impact of science and technology on quality of life, ethical implications, stimulating the interest of young people in science subjects (Freeman et al., 2014), gender issues, and open access to research results. The application of innovative strategies such as flipped classrooms and learning by doing must become common practice in the education of the future. This would also promote the fundamental role played by education in competitiveness and the future economic development of countries.

7) Education and Culture: Reading, thinking, imagining and creating are human actions that have been modified in the digital era, which has accelerated the future (Merrit, 2014, Kukulska-Hulme, 2010). What is essential are the individual's free options, forms of freedom of choice that will configure the future that will create new environments such as libraries without books, art galleries without artworks, and classrooms without teachers (Prince, 2014).

8) Smart cities: The creation of transformative environments for the emergence of talent, the definition of functions, and the profile of cities as education resources in themselves (Chourabi, 2012) should guarantee free and universal access to the Internet and its resources in order to prevent cultural inequality, especially with regard to the attainment of learning opportunities. The traditional view of the city should 
be reconceptualized towards an inclusive, modern and open environment (Trilla, 2007) where technology permeates its every component and enables its citizens to use their city as a true learning laboratory for their own benefit (Innerarity, 2011).

9) Ethics and Technology: Technology, values and individuals interact with each other to influence social and cultural development, and these interactions are in turn determined by society and culture. Values act as regulators of the decisions taken by individuals (Camps, 1993) regarding the use of technologies in education when the benefits or potential dangers entailed individually or collectively in those decisions are considered or disregarded (INTECO, 2012).

10) Inclusion and Social Cohesion: Broadly speaking, the challenges facing an inclusive education model include a lack of effective mechanisms for sharing the knowledge generated, a lack of criteria for objectivizing results, a narrow curricular definition of digital competence (which can widen both the digital divide and the social divide) (Juárez and Avellaneda, 2011), the limited access to digital content, and a lack of planning in the deployment of ICTs in formal and non-formal education (Travieso and Planella, 2008).

11) Social networks: Digital networks have changed how we interact with society. The answers to the following two questions are fundamental: (i) how do these digital networks reflect our society?, and (ii) how can they help to transform how we interact in order to achieve certain objectives? (Girvan and Newman, 2002). To answer these questions, we need to focus our analysis on the impact of social networks in three areas: education and learning, the dissemination of knowledge (Jubany, 2012), and citizen involvement (Hand, 2010).

Below we present a summary of the experts' working methodology. This methodology enabled the state of the art in each thematic line to be analyzed, pondered and debated and proposals for innovations, improvements and changes for the next five years to be made based on conclusions drawn from a "glocal" perspective.

\section{Working methodology}

As we have mentioned, the work of the experts was organized along eleven thematic lines within four thematic axes. Each thematic line was divided into two subgroups, one of which comprised experts from Catalonia and the other comprised international experts. Each subgroup was led by an expert from the URV who was also a member of the ARGET [Ref. 2014SGR1399] or BIOCENIT [Ref. 2014SGR1352] research group, which during the first phase designed this first FIET from the scientific perspective. In the second phase, an interuniversity group of experts from every university in Catalonia was created. Each subgroup comprised one (Catalan or international) leader and three experts. Each Catalan university assumed responsibility for leading one of the lines, while the general organization was performed by various working groups:

\section{- The Steering Committee}

This executive committee was mainly made up of experts from the URV, who were responsible for organizing the Forum generally, defining the Forum's general contents, and organizing and managing the online Forum, etc. 


\section{- The Scientific Committee}

This committee was made up of the leaders (both Catalan and international) of the eleven thematic lines (i.e. 22 leaders in total), who were responsible for defining the indicators for selecting the best experiences in Education and Technology, drafting a framework document to outline the contents of the thematic line from a dual Catalan and international perspective and define the lines of action to be implemented in Catalonia in the fields of Education, Culture and Technology over the next five years.

\section{- The working teams}

As well as a Catalan leader and an international leader, each FIET thematic line comprised a URV representative plus a group of experts - professionals of renowned prestige in the field of Education and Technology research who were able to provide current, expert and innovative perspectives on the thematic line concerned.

Below we summarize the phases involved in managing the information and knowledge provided by the experts and drawing up the final documents for each thematic line.

Table 1. Phases of the work conducted by the FIET experts

\begin{tabular}{|c|c|}
\hline Phases & Tasks \\
\hline F0. Identify the knowledge & $\begin{array}{l}\text { — Identify the best professionals in Catalonia and from around the world. } \\
\text { — Identify the best experiences locally and internationally. } \\
\text { — Define the general indicators for selecting and evaluating good praxis. }\end{array}$ \\
\hline F1. Organize the online Forum & $\begin{array}{l}\text { — Select the technological tools needed for the online work. } \\
\text { — Design the collaborative working environment. } \\
\text { — Define guidelines for the shared work: } \\
\text { - Define the work calendar. } \\
\text { - Organize the tasks. } \\
\text { - Define the framework contents for each thematic line. }\end{array}$ \\
\hline F2. Hold a meeting of the group leaders & $\begin{array}{l}\text { - Analyze and discuss the first draft report for each thematic line. } \\
\text { — Conduct the first review of the experiences selected. }\end{array}$ \\
\hline F3. Hold the Scientific Forum & $\begin{array}{l}\text { - Organize a meeting of all leaders and experts. } \\
\text { — Share knowledge and experiences. } \\
\text { — Conclude the framework document for each thematic line with the contributions } \\
\text { from all the experts. } \\
\text { - Draw up recommendations and agree on proposals. }\end{array}$ \\
\hline F4. Hold the Public Forum & $\begin{array}{l}\text { - Share the knowledge and experiences of the leaders and experts at an event } \\
\text { attended by an audience specializing in Education and Technology. }\end{array}$ \\
\hline
\end{tabular}

In the next section we summarize the main results gathered from this work, exchange and collaboration process conducted between September 2013 and June 2014.

\section{Strategic lines for the near future}

During these nine months of collaborative work, many synergies were generated among the researchers. These synergies enabled the status quo in Catalonia on the digitization of education and culture to be compared with 
that of the other participating countries and led to the initiation of collaborative processes and projects that created possibilities for joint work between researchers of different institutions and areas of knowledge. We consider this interdisciplinary and transnational perspective to be one of the greatest contributions of the Forum.

In view of the breadth and scope of the range of topics discussed at the Forum, we present below by way of conclusion what were considered by all to be strategic axes for investigation and intervention and provide our main recommendations for the successful implementation of actions:

\section{- Institutions and learning environments:}

- Smart technology should be integrated given its potential as a learning environment.

- New learning environments should be designed and developed with collaboration from various agents of education. Formal teaching centers alone no longer cover all educational needs.

\section{- Citizens:}

- Social responsibility in the use of technology should be adequately developed.

- Critical thinking and opportunities for the creative construction of knowledge should be promoted.

- Digital competence is essential if individuals are to develop in a digital society.

\section{- Teachers:}

- Teachers need to improve their digital competence and be trained in matters of ethics.

- The use of innovative methodologies that introduce ICTs into educative processes should be encouraged and supported.

- Initial and continuous teacher training programs to improve teachers' digital competences should be designed and developed.

- A map of educational innovation from an international perspective should be drawn up and used for example purposes.

\section{- Public policies:}

- Education policies that look beyond the formal education system should be defined.

- Quality in the use of ICTs in education should be promoted.

- Educational autonomy for developing innovation should be supported.

- Digital tools should be provided to ensure universal access to information and knowledge.

- Cultural, institutional and curricular patterns should be modified and flexibility and adaptation to the digital reality should be ensured.

- Ethical codes on the use of technology should be developed.

To be successful, each recommendation needs to be supported by public administrations, technology developing companies, and education communities, as well as by the citizens, who are required to develop personally and professionally in a complex and continually changing digital context that requires them to have a proactive and innovative attitude and be prepared to undertake a process of lifelong learning. The research conducted and evidence acquired should allow us to transform the education process with technology as our principal ally. 


\section{References}

Adell, J. (2013). Los MOOC, en la cresta de la ola. Educación y tecnología. 19-03-2013. http://elbonia.cent.uji.es/ jordi/2013/03/19/los-moocs-en-la-cresta-de-la-ola/

Adell, J., \& Castañeda, L. (2013). El ecosistema pedagógico de los PLEs. In L. Castañeda, J. Adell (Eds.). Entornos Personales de Aprendizaje: Claves para el ecosistema educativo en red (pp. 29-51). Alcoy: Marfil.

Barber, M., \& Mourshed, M. (2007). How the World's Best School Systems Come Out on Top. In M. Company (Ed.). London: McKinsey Company.

Bonal, X. T., \& Verger, A. (2013). L'agenda de la política educativa a Catalunya: una anàlisi de les opcions de govern (2011-2013). Barcelona: Fundació Jaume Bofill.

Brown, P., Lauder, H., \& Ashton, D. (2011). The Global Auction: The Broken Promises of Education, Jobs and Incomes. Oxford: Oxford University Press. doi: http://dx.doi.org/10.1093/acprof:oso/9780199731688.001.0001

Camps, V. (1993). Los valores en educación. Madrid: Anaya/Alauda.

Castells, M. (2004). The network society. A cross-cultural perspective. Massachusetts: Edward Elgar.

Comisión Europea. (2012). Un nuevo concepto de educación: Invertir en las competencias para lograr mejores resultados socioeconómicos. Strasbourg.

Chourabi, H., Nam, T., Walker, S., Gil-Garcia, J.R., Mellouli, S., Nahon, K., Pardo, T., \& Scholl, H. J. (2012). Understanding Smart Cities: An Integrative Framework, Proceedings of the 45th Hawaii International Conference on System Sciences. doi: http://dx.doi.org/10.1109/HICSS.2012.615

Dalgarno, B., \& Lee, M. J. W. (2010). What are the learning affordances of 3D virtual environments? British Journal of Educational Technology, 41(1), 10-32.

European Commission. (2007). Key competences for lifelong learning. European reference framework.

European Commission/EACEA/Eurydice. (2013). Education and Training in Europe 2020: Responses from the EU Member States. Eurydice Report. Brussels: Eurydice. http://eacea.ec.europa.eu/education/eurydice/documents/ thematic_reports/163EN.pdf

European Union. (2010). Digital agenda for Europe. http://ec.europa.eu/digital-agenda

Freeman, S., Eddy, S. L., McDonough, M., Smith, M. K., Okoroafor, N., Jordt, H., \& Wenderoth, M. P. (2014). Active learning increases student performance in science, engineering, and mathematics. PNAS, 111(23), 8410-8415. doi: http://dx.doi.org/10.1073/pnas.1319030111

Gairín, J. (2005). (Coord.). La descentralización educativa: ¿una solución o un problema? Barcelona: Praxis.

Gairín, J., Armengol, C., \& Muñoz, J. L. (2010). La innovación educativa en las comunidades autónomas de Cataluña y Aragón. Profesorado. Revista de currículum y formación del profesorado, 14, 21.

Generalitat de Catalunya. (2013). Agenda digital per a Catalunya 2020 (idigital). Retrieved from http://www.idigital. cat/documents/10501/405750/Agenda_Digital_CAT_maquetada.pdf

Girvan, M., \& Newman, M. E. (2002). Community structure in social and biological networks. Proceedings of the National Academy of Sciences, 99(12), 7821-7826.

Gordó, G. (2010) Centros educativos: ¿islas o nodos? Los centros como organizaciones-red. Barcelona: Graó.

Granieri, M., \& Renda, A. (2012) Innovation Law and Policy in the European Union: Towards Horizon 2020. Milan: Springer-Verlag.

Gros, B. (2012). Retos y tendencias sobre el futuro de la investigación acerca del aprendizaje con tecnologías digitales. RED, Revista de Educación a Distancia, 32. Retrieved from http://www.um.es/ead/red/32 
Hand, E. (2010) Citizen science: People power. Nature, Vol. 466, No. 7307, pp. 685-687. doi: http://dx.doi. org/10.1038/466685a

Innerarity, D. (2011). La democracia del conocimiento. Por una sociedad inteligente. Barcelona: Espasa Libros.

Instituto Nacional de Tecnologías de la Comunicación (INTECO). (2012). Guía para usuarios: identidad digital y reputación online. Madrid. Retrieved from http://www.inteco.es/guias_estudios/guias/Guia_Identidad_ Reputacion_usuarios

Johnson, L., Adams Becker, S., Cummins, M., Estrada, V., Freeman, A., \& Ludgate, H. (2013). NMC Horizon Report: Edición sobre Educación Superior 2013. Austin, Texas: The New Media Consortium.

Johnson, L., Adams, S., Estrada, V., \& Freeman, A. (2014). NMC Horizon Report: 2014 Higher Education Edition. Austin, Texas: The New Media Consortium.

Johnson, L., Adams, S., \& Cummins, M. (2012). Informe Horizon del NMC: Edición para la enseñanza universitaria 2012.

Austin, Texas: The New Media Consortium.

Juárez, P., \& Avellaneda, N. (2011). Red de Tecnologías para la Inclusión Social. Construyendo conocimiento científico y tecnológico entre Estado, Universidades, Cooperativas de Trabajo y OSC. XI Congreso Iberoamericano de Extensión Universitaria Integración, Extensión, Docencia e Investigación para la Inclusión y Cohesión Social. Santa Fe, 22-25 November 2011.

Jubany, J. (2012). Aprendizaje social y personalizado: conectarse para aprender. Colección Sociedad y Red. Barcelona: Editorial UOC.

Kartensi, T. (2013).The MOOC. What the research says. International Journal of Technologies in Higher Education, 10, pp. 23-37. http://www.ritpu.org/spip.php?rubrique73\&lang=en

Katic, E. (2008). Preservice teachers' conceptions about computers: An ongoing search for transformative appropriations of modern technologies. Teachers and Teaching, 14(2), 157-179. doi: http://dx.doi. org/10.1080/13540600801983344

Kereluik, K., Mishra, P., Fahnoe, C., \& Terry, L. (2012). What knowledge is of most worth: Teacher knowledge for $21^{\text {st }}$ century learning. Journal of Digital Learning in Teacher Education, 29(4), 127-140.

Kukulska-Hulme, A. (2010). Learning cultures on the move: where are we heading? Educational Technology \& Society, 13(4), 4-14

Linn, M. C., \& Eylon, B. S. (2011). Science Learning and Instruction: Taking Advantage of Technology to Promote Knowledge Integration. New York, NY: Routledge.

Mahiri, J. (2011). Digital tools in urban schools. Mediating a remix of learning. Ann Arbor, Ml: University of Michigan Press. doi: http://dx.doi.org/10.3998/toi.10329379.0001.001

Mansell, R., \& Tremblay, G. (2013). Renewing the knowledge societies vision for peace and sustainable development. Paris: United Nations Educational, Scientific and Cultural Organization (UNESCO).

Martínez Bonafé, J. (2012). El problema del conocimiento en el triángulo entre capitalismo, crisis y educación. Investigación en la Escuela, 76, pp. 7-22.

Martínez, M., \& Albaigés, B. (Directors). (2013). L'estat de l'educació a Catalunya. Anuari 2013. Barcelona: Fundació Jaume Bofill, Polítiques, 80. http://www.fbofill.cat/intra/fbofill/documents/publicacions/582.pdf

Merrit, E. (2014). About this convening. In Building the future of Education: Museums and the Learning Ecosystem, pp. 7-8. American Alliance of Museums.

Mishra, P., \& Kereluik, K. (2011). What 21 ${ }^{\text {st }}$ century learning? A review and a synthesis. In SITE Conference. 5-236. OECD. (2012). Better skills, better jobs, better lives: A strategic approach to skills policies. OECD Publishing. 
Pedró, F. (2011). Tecnología en la escuela: Lo que funciona y porqué. Madrid: Fundación Santillana.

Prats, E. (2013). L'educació, una qüestió d'estat. Una mirada a Europa. Barcelona: Universitat de Barcelona.

Prince, K. (2014). Glimpses of the future of education. In Building the Future of Education: Museums and the Learning Ecosystem, pp. 14-20. American Alliance of Museums.

Salinas, J. (2005). Nuevos escenarios de aprendizaje. Grupo CIFO: IV Congreso de Formación para el Trabajo, pp. 421-431. IFES, Fundación Forcem and Universidad de Vigo, 2005.

Sarramona, J. (2011). Les competències i els aprenentatges en un món globalitzat. Les 3 coses que he après. Debats d'Educació. UOC/Fundació Jaume Bofill. http://les3coses.debats.cat/ca/expert/jaume-sarramona

Slavich, G. M., \& Zimbardo, P. G. (2012). Transformational Teaching: Theoretical Underpinnings, Basic Principles, and Core Methods. Educational Psychology Review, 24(4), 569-608. doi: http://dx.doi.org/10.1007/s10648-012-9199-6 Travieso, J. L., \& Planella, J. (2008). La alfabetización digital como factor de inclusión social: una mirada crítica. UOC Papers N.6. UOC. ISSN 1885-1541. Retrieved from http://www.uoc.edu/uocpapers/6/dt/esp/travieso_planella. pdf

Trilla, J. (2007). La educación no formal y la ciudad educadora. In Casanova, H., \& Lozano, C. (Coords.). Educación, universidad y sociedad: el vínculo crítico, pp. 23-42. Mexico: Publicaciones de la Universidad Nacional Autónoma de México.

Twining, P., Raffaghelli, J., Albion, P., \& Knezek, D. (2013). Moving education into the digital age: the contribution of teachers' professional development. Journal of Computer Assisted Learning, 29(5), 426-437. doi: http://dx.doi.org/10.1111/jcal.12031

\section{About the authors}

Mercè Gisbert Cervera

merce.gisbert@urv.cat

ORCID ID: http://orcid.org/0000-0002-8330-1495

Professor in the Department of Education at the Rovira i Virgili University (URV), Spain

With a PhD in Educational Sciences, Mercè Gisbert Cervera has been a professor in the Department of Education of the Rovira i Virgili University for the last twenty-five years. A specialist in technology applied to education, she is the coordinator of ARGET (Applied Research Group in Education and Technology) and of the interuniversity doctorate in Educational Technology.

Universitat Rovira i Virgili

Facultat de Ciències de l'Educació i Psicologia

Carretera de Valls, s/n

43007 Tarragona

Spain 


\author{
Larry Johnson \\ johnson@nmc.org \\ ORCID ID: http://orcid.org/0000-0003-1120-6664 \\ Chief Executive Officer and Board Member of the New Media Consortium (NMC), USA
}

Laurence F. Johnson, Ph.D. is the founder of the Horizon Project, which produces the acclaimed series of Horizon Reports that are now used by more than five million educators in nearly 200 countries, and Chief Executive Officer of the New Media Consortium, an international not-for-profit consortium dedicated to the exploration and use of new media and new technologies. With more than 30 years of experience in the higher education arena, he served in roles from professor to dean, $\mathrm{ClO}$ and provost, and president before joining the NMC in 2001.

1250 S Capital of Texas Highway

Bldg. 3 Suite 400

Austin, TX 78746

USA

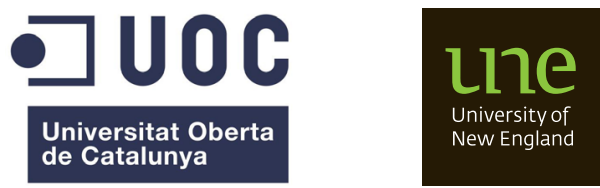

